\title{
PROFIL HEMATOLOGI PADA PENDERITA DIARE AKUT YANG DIRAWAT DI BAGIAN ILMU KESEHATAN ANAK RSUP PROF. DR. R. D. KANDOU MANADO PERIODE NOVEMBER 2010 - NOVEMBER 2011
}

\author{
${ }^{1}$ Yotmiro S. Rottie \\ ${ }^{2}$ Max F. J. Mantik \\ ${ }^{2}$ Ari L. Runtunuwu
}

\author{
${ }^{1}$ Kandidat Skripsi Fakultas Kedokteran Universitas Sam Ratulangi \\ ${ }^{2}$ Bagian Ilmu Kesehatan Anak Kedokteran Universitas Sam Ratulangi \\ Email: saktobart@gmail.com
}

\begin{abstract}
Diarrhea is an abnormal excretion of stool or dilute form of feces with abnormal frequency. Neonatal can be diagnosed with diarhhea when the frequency of bowel movements is more than 4 times per day. In babies aged 1 month old or older, diarhhea is diagnosed when the frequency is more than 3 times per day. Until today, diarrhea is still a health problem in Indonesia as well as in other developing countries. Diarrhea that occurs less than 14 days is called acute diarhhea. There are many causes of diarrhea inter alia infectious and non infectious diseases. The complications of acute diarrhea can be dehydration, hypovolemic shock, hypokalemia, and hypoglycemia. Hematological examination of acute diarrhea patients with severe dehydration can be increased hematocrit and hemoglobin. This study aimed to obtain the hematological results of acute diarrhea patients at the Paediatrics Department of Prof Dr. R. D. Kandou Hospital, Manado. This was a retrospective descriptive study by using medical records. In this study, there were 276 patients in the period November 2010 November 2011. The results showed that of the 276 patients with acute diarrhea, 157 patients were males (55.88\%) and 115 patients were females (43.12\%). Concerning the hematological examination, 205 patients (74.27\%) had normal hematocrit, 189 patients $(68.48 \%)$ had normal hemoglobin, and 224 patients (81.16\%) had normal leukocyte counts, and 196 patients (71.01\%) had normal platelet counts. There were 273 patients $(98.91 \%)$ with length of treatment $1-\leq 14$ days meanwhile 3 patients (1.09\%) with length of treatment $>14$ days.
\end{abstract} Keywords: acute diarrhea, hematological examination, children

\footnotetext{
Abstrak: Diare adalah pengeluaran tinja yang tidak normal atau bentuk tinja yang encer dengan frekuensi lebih banyak dari biasanya. Neonatus dinyatakan diare bila frekuensi buang air besar sudah lebih dari 4 kali, sedangkan bayi berumur lebih dari 1 bulan dan anak, bila frekuensinya lebih dari 3 kali, sampai saat ini, diare masih menjadi masalah kesehatan di Indonesia juga dinegara-negara berkembang, diare disebut akut bila terjadi kurang dari 14 hari, diare dapat disebabkan oleh berbagai hal yaitu infeksi maupun non infeksi, pada diare akut dapat terjadi komplikasi antara lain dehidrasi, renjatan hipovolemik, hipokalemia, hipoglekemia, pemeriksaan hematologi pasien diare akut dapat terjadi peningkatan pada beberapa pemeriksaan darah seperti peningkatan hematokrit dan hemoglobin pada keadaan dehidrasi berat. Penelitian ini bertujuan untuk melihat gambaran hematologi pada pasien diare akut di bagian Ilmu Kesehatan Anak RSUP Prof. Dr. R. D. Kandou Manado. Penelitian ini menggunakan metode deskriptif retrospektif dengan memanfaatkan catatan rekam medik. Sampel penelitian ini 276 pasien dengan diare akut pada periode November 2010 - November 2011. Dari 276 pasien, didapatkan laki-laki 157 (55,88\%) pasien dan perempuan 115 (43,12\%) pasien. Pada pemeriksan hematologi didapatkan nilai hematokrit normal 205 (74,27\%) pasien,
} 
hemoglobin normal 189 (68,48\%) pasien, hitung leukosit normal 224 (81,16\%) pasien, dan hitung trombosit normal $196(71,01 \%)$ pasien. Terdapat 273 (98,91\%) pasien dengan lama perawatan 1 - $\leq 14$ hari dan 3 (1,09\%) pasien dengan lama perawatan >14 hari.

Kata kunci: diare akut, pemeriksaan hematologi, pasien anak

Diare adalah pengeluaran tinja yang tidak normal atau bentuk tinja yang encer dengan frekuensi lebih banyak dari biasanya. Neonatus dinyatakan diare bila frekuensi buang air besar sudah lebih dari 4 kali, sedangkan bayi berumur lebih dari 1 bulan dan anak, bila frekuensinya lebih dari 3 kali. Bayi dan balita sering terserang infeksi seperti diare. Diare dapat disebabkan oleh berbagai hal yaitu infeksi maupun non infeksi. Sekitar 30-40\% diare yang terjadi pada balita di Indonesia disebabkan oleh infeksi rotavirus. ${ }^{1-3}$ Sampai saat ini, diare masih menjadi masalah kesehatan di indonesia.

Diare merupakan penyebab utama kesakitan dan kematian pada anak di negara berkembang dengan perkiraan 1,3 miliar kejadian dan 3,2 juta kematian setiap tahun pada balita. Secara keseluruhan, anak-anak mengalami diare rata-rata 3,3 kejadian pertahun, pada beberapa tempat dapat lebih dari 9 kejadian pertahun. Pada daerah dengan kejadian diare yang tinggi, seorang balita dapat menghabiskan 15\% waktunya dengan diare. Kurang lebih $80 \%$ kematian yang berhubungan dengan diare terjadi pada 2 tahun pertama kehidupan. ${ }^{4}$

Dalam profil kesehatan Indonesia tahun 2004 menuju Indonesia sehat 2010 ditemukan 6.478 .804 balita mengalami diare; 24.521 kasus merupakan balita di Sulawesi Utara. ${ }^{5}$

Menurut WHO, lebih dari 1,5 juta anak dibawah 5 tahun meninggal setiap tahunnya akibat diare akut. Meskipun angka kematian balita per tahun karena diare akut telah menurun drastis dari 4,5 juta di tahun 1979 menjadi 1,6 juta di tahun 2002, penyakit ini tetap menjadi pembunuh utama pada anak-anak terutama di negara berkembang. ${ }^{6}$

Untuk mencegah komplikasi dan demi kepentingan penatalaksanaan diare yang tepat, maka diperlukan ketepatan dalam mendiagnosis derajat dan penyebab penyakit tersebut. Pemeriksaan yang mendukung diagnosis diare antara lain meliputi anamnesis, pemeriksaan fisik, pemeriksaan feses, kultur feses, pemeriksaan darah, dan sigmoidoskopi. Pada praktek sehari-harinya, kedua pemeriksaan yang disebutkan terakhir merupakan yang paling jarang dilakukan. Memang pada kenyataannya, pemeriksaan darah memiliki nilai diagnosis yang kurang bermakna dibandingkan pemeriksaan yang lain terutama pada kasus diare akut. Namun tidak dapat dipungkiri bahwa gambaran hematologi pada pasien diare dapat membantu dokter untuk menegakkan diagnosis, antara lain dalam menyingkirkan beberapa penyakit tertentu. $^{7}$

\section{METODE PENELITIAN}

Penelitian ini bersifat deskriptif retrospektif. Penelitian dilakukan di bagian Ilmu Kesehatan Anak RSUP Prof. Dr. R. D. Kandou Manado selama bulan November 2011 - Januari 2012. Variabel yang digunakan merupakan variabel tetap dan variabel bebas. Subjek penelitian yang digunakan merupakan penderita yang dirawat di bagian Ilmu Kesehatan Anak RSUP Prof. Dr. R. D. Kandou Manado yang terdiagnosis diare akut pada periode November 2010 - november 2011. Cara kerja dengan metode pengumpulan data serta analisis dan cara penyajian data.

Diare adalah perubahan frekuensi buang air besar yang lebih dari biasanya (lebih dari 3 kali sehari) dan konsistensi tinja yang melembek sampai cair, dapat disertai darah dan lendir pada tinja. Diare akut adalah diare yang berlangsung selama kurang dari 14 hari.

Kelompok umur ialah: 1 bulan $-<1$ tahun; 3 tahun $-<5$ tahun; dan 4 tahun $-<$ 11 tahun. Pemeriksaan darah rutin meliputi: Hematokrit (Tabel 1), hemoglobin (Tabel 
2), leukosit (Tabel 3), dan trombosit (Tabel 4).

Tabel 1. Nilai hematokrit untuk anak. ${ }^{10}$

\begin{tabular}{cc}
\hline Umur & $\begin{array}{c}\text { Nilai rujukan } \\
(\%)\end{array}$ \\
\hline 0-7hari & $42-60$ \\
8-14hari & $39-60$ \\
13-30hari & $31-55$ \\
1-6bulan & $26-42$ \\
0,5-6tahun & $33-40$ \\
6-11tahun & \\
- Laki-laki & $36-42$ \\
- Perempuan & $36-43$ \\
12-16tahun & \\
- Laki-laki & $37-47$ \\
- Perempuan & $36-43$ \\
\hline
\end{tabular}

Tabel 2. Nilai rujukan hemoglobin untuk anak. $^{11}$

\begin{tabular}{cc}
\hline Umur & $\begin{array}{c}\text { Nilai rujukan } \\
(\mathrm{g} / \mathrm{dl})\end{array}$ \\
\hline 1 hari & $15,2-23,6$ \\
$2-6$ hari & $15-24,6$ \\
$14-23$ hari & $12,7-18,7$ \\
$24-37$ hari & $10,3-17,9$ \\
$40-50$ hari & $9,0-16,6$ \\
$2-2,5$ bulan & $9,2-13,6$ \\
$3-3,5$ bulan & $9,61-12,8$ \\
$5-7$ bulan & $10,1-12,9$ \\
8-10 bulan & $10,5-12,9$ \\
$11-13,5$ bulan & $10,7-13,1$ \\
$1,5-3$ tahun & $10,8-12,8$ \\
5 tahun & $10,7-14,7$ \\
10 tahun & $10,8-15,6$ \\
12 tahun & $11,8-15,0$ \\
15 tahun & $12,8-16,8$ \\
\hline
\end{tabular}

Tabel 3. Nilai rujukan leukosit untuk anak. ${ }^{11}$

\begin{tabular}{cc}
\hline Umur & $\begin{array}{c}\text { Nilai rujukan } \\
\left(1000 / \mathrm{mm}^{3}\right)\end{array}$ \\
\hline 12 jam & $9-30$ \\
24 jam & $19-38$ \\
1 mingu & $9,4-34$ \\
2 minggu & $5-21$ \\
1 bulan & $5-20$ \\
6 bulan & $5-19,5$ \\
1 tahun & $6-17,5$ \\
2 tahun & $6-17$ \\
4 tahun & $5,5-14,5$ \\
6 tahun & $5-14,5$
\end{tabular}

\begin{tabular}{cc}
8 tahun & $4,5-13,5$ \\
10 tahun & $4,5-13,5$ \\
16 tahun & $4,5-13$ \\
\hline
\end{tabular}

Tabel 4. Nilai rujukan trombosit untuk anak. ${ }^{10}$

\begin{tabular}{cc}
\hline Umur & Trombosit $\left(/ \mathrm{mm}^{3}\right)$ \\
\hline 24 jam-2 tahun & $200.000-4000.000$ \\
3-6 tahun & $240.000-570.000$ \\
6-16 tahun & $200.000-500.000$ \\
\hline
\end{tabular}

\section{HASIL PENELITIAN}

Berdasarkan penelitian yang dilakukan secara retrospektif di bagian IKA RSUP Prof. Dr. R. D. Kandou periode November 2010 - November 2011 didapatkan 276 orang pasien diare akut. Tabel 5 memperlihatkan bahwa dari 276 pasien penderita diare akut terdapat 157 orang anak (56.88\%) dengan jenis kelamin laki-laki dan 119 orang anak (43.12\%) dengan jenis kelamin perempuan.

Tabel 5. Distribusi pasien diare akut berdasarkan jenis kelamin

\begin{tabular}{ccc}
\hline $\begin{array}{c}\text { Jenis } \\
\text { kelamin }\end{array}$ & Jumlah & $\mathbf{( \% )}$ \\
\hline Laki-laki & 157 & 55,88 \\
Perempuan & 119 & 43,12 \\
Total & 276 & 100 \\
\hline
\end{tabular}

Tabel 6. Distribusi pasien diare akut berdasarkan umur

\begin{tabular}{ccc}
\hline Umur & Jumlah & $(\%)$ \\
\hline 1 bulan $-<1$ tahun & 122 & 44,20 \\
1 tahun $-<3$ tahun & 118 & 42,75 \\
3 tahun $-<5$ tahun & 21 & 7,61 \\
$5-<11$ tahun & 15 & 5,44 \\
\hline Total & 276 & 100 \\
\hline
\end{tabular}

Dari Tabel 6 didapatkan bahwa dari 276 pasien penderita diare akut terdapat 122 orang anak (44,20\%) berumur 1 bulan - <1 tahun, 118 orang anak (42,75\%) berumur 1 tahun $-<3$ tahun, 21 orang anak (7,61\%) berumur 3 tahun $-<5$ tahun, 15 orang anak $(5,44 \%)$ berumur $5-<11$ tahun.

Dari Tabel 7 didapatkan bahwa dari 276 pasien penderita diare akut terdapat 40 orang anak (14,50\%) dengan nilai 
hematokrit di bawah normal, 205 orang anak $(74,27 \%)$ dengan nilai hematokrit normal, 31 orang anak $(11,23 \%)$ dengan nilai hematokrit di atas normal.

Tabel 7. Distribusi pasien diare akut berdasarkan nilai hematokrit

\begin{tabular}{ccc}
\hline Hematokrit & Jumlah & $\mathbf{( \% )}$ \\
\hline$<$ normal & 40 & 14,50 \\
Normal & 205 & 74,27 \\
$>$ normal & 31 & 11,23 \\
Total & 276 & 100 \\
\hline
\end{tabular}

Dari Tabel 8 didapatkan bahwa dari 276 pasien penderita diare akut terdapat 22 orang anak (7,98\%) dengan nilai leukosit di bawah normal, 224 orang anak (81,16\%) dengan nilai leukosit normal, 30 orang anak $(10,86 \%)$ dengan nilai leukosit di atas normal.

Tabel 8. Distribusi pasien diare akut berdasarkan nilai leukosit

\begin{tabular}{ccc}
\hline Leukosit & Jumlah & $(\%)$ \\
\hline$<$ normal & 22 & 7,98 \\
Normal & 224 & 81,16 \\
> normal & 30 & 10,86 \\
Total & 276 & 100 \\
\hline
\end{tabular}

Dari Tabel 9 didapatkan bahwa dari 276 pasien penderita diare akut terdapat 37 orang anak $(13,41 \%)$ dengan nilai hemoglobin di bawah normal, 189 orang anak (68,48\%) dengan nilai hemoglobin normal, 50 orang anak (18,11\%) dengan nilai hemoglobin di atas normal.

Tabel 9. Distribusi pasien diare akut berdasarkan nilai hemoglobin

\begin{tabular}{ccc}
\hline Hemoglobin & Jumlah & $(\%)$ \\
\hline$<$ normal & 37 & 13,41 \\
Normal & 189 & 68,48 \\
$>$ normal & 50 & 18,11 \\
Total & 276 & 100 \\
\hline
\end{tabular}

Dari Tabel 10 didapatkan bahwa dari 276 pasien penderita diare akut terdapat 18 orang anak (6.52\%) dengan nilai trombosit di bawah normal, 196 orang anak (71,01\%) dengan nilai trombosit normal, 62 orang anak $(22,47 \%)$ dengan nilai trombosit di atas normal.

Tabel 10. Distribusi pasien diare akut berdasarkan nilai trombosit

\begin{tabular}{ccc}
\hline Trombosit & Jumlah & $\mathbf{( \% )}$ \\
\hline$<$ normal & 18 & 6,52 \\
Normal & 196 & 71,01 \\
$>$ normal & 62 & 22,47 \\
Total & 276 & 100 \\
\hline
\end{tabular}

Dari Tabel 11 didapatkan bahwa dari 276 pasien penderita diare akut terdapat 133 orang anak $(48,19 \%)$ tanpa dehidrasi, 132 orang anak (47,83\%) dengan dehidrasi ringan-sedang, 11 orang anak (3,98\%) dengan dehidrasi berat.

Tabel 11. Distribusi pasien diare akut berdasarkan derajat dehidrasi

\begin{tabular}{ccc}
\hline Derajat dehidrasi & Jumlah & $\mathbf{( \% )}$ \\
\hline Tanpa dehidrasi & 133 & 48,19 \\
Ringan - sedang & 132 & 47,83 \\
Berat & 11 & 3,98 \\
Total & 276 & 100 \\
\hline
\end{tabular}

Dari Tabel 12 didapatkan bahwa dari 11 pasien penderita diare akut dengan dehidrasi berat terdapat 2 orang anak (19\%) dengan nilai hematokrit di bawah normal, 6 orang anak (54\%) dengan nilai hematokrit normal, 3 orang anak (27\%) dengan nilai hematokrit di atas normal.

Tabel 12. Distribusi pasien diare akut dengan dehidrasi berat berdasarkan nilai hematokrit

\begin{tabular}{ccc}
\hline Hematokrit & Jumlah & $(\%)$ \\
\hline$<$ normal & 2 & 19 \\
Normal & 6 & 54 \\
$>$ normal & 3 & 27 \\
Total & 11 & 100 \\
\hline
\end{tabular}

Dari Tabel 13 didapatkan bahwa dari 276 pasien penderita diare akut tidak terdapat anak dengan gizi buruk, 63 orang anak (22,83\%) dengan gizi kurang, 210 orang anak (76,09\%) dengan gizi baik, 2 orang anak $(0,72 \%)$ dengan overweight, 1 
orang anak (0,36\%) dengan obesitas.

Tabel 13. Distribusi pasien diare akut berdasarkan status gizi

\begin{tabular}{ccc}
\hline Status gizi & Jumlah & $(\%)$ \\
\hline Gizi buruk & 0 & 0 \\
Gizi kurang & 63 & 22,83 \\
Gizi baik & 210 & 76,09 \\
Overweight & 2 & 0,72 \\
Obesitas & 1 & 0,36 \\
Total & 276 & 100 \\
\hline
\end{tabular}

Dari Tabel 14 didapatkan bahwa dari 276 pasien penderita diare akut terdapat 122 orang anak $(44,20 \%)$ yang disertai faktor penyulit, 154 orang anak (55,80\%) tidak disertai dengan faktor penyulit.

Tabel 14. Distribusi pasien diare akut berdasarkan faktor penyulit

\begin{tabular}{ccc}
\hline $\begin{array}{c}\text { Faktor } \\
\text { penyulit }\end{array}$ & Jumlah & $(\%)$ \\
\hline Ada & 122 & 44,20 \\
Tidak & 154 & 55,80 \\
Total & 276 & 100 \\
\hline
\end{tabular}

Dari Tabel 15 didapatkan bahwa dari 276 pasien penderita diare akut berdasarkan lama perawatan terdapat 273 orang anak (98,91\%) yang dirawat $1-\leq 14$ hari, 3 orang anak (1,09\%) yang dirawat $>14$ hari.

Tabel 15. Distribusi pasien diare akut berdasarkan lama perawatan

\begin{tabular}{ccc}
\hline Lama & Jumlah & $(\%)$ \\
perawatan & & \\
\hline $1-\leq 14$ hari & 273 & 98,91 \\
$>14$ hari & 3 & 1,09 \\
Total & 276 & 100 \\
\hline
\end{tabular}

\section{BAHASAN}

Berdasarkan penelitian yang dilakukan di bagian IKA RSUP Prof. Dr. R. D. Kandou periode November 2010 November 2011 didapatkan jumlah penderita diare akut sebanyak 276 orang anak. Dari Tabel 5, distribusi pasien diare akut berdasarkan jenis kelamin, terdapat 157 orang anak (56,88\%) dengan jenis kelamin laki-laki dan 119 orang anak (43,12\%) dengan jenis kelamin perempuan. Sesuai dengan kepustakaan, jenis kelamin bukan merupakan faktor yang berpengaruh terhadap kejadian diare. Faktor-faktor resiko dari diare antara lain lingkungan dan paparan enteropatogen. Faktor resiko tambahan antara lain usia muda, defisiensi imun, campak, gizi buruk, ASI yang tidak eksklusif. $^{12}$ Dari Tabel 6, di distribusi pasien diare akut berdasarkan umur, terdapat 122 orang anak (44,20\%) berumur 1 bulan $-<1$ tahun, 118 orang anak (42,75\%) berumur 1 tahun $-<3$ tahun, 21 orang anak (7,61\%) berumur 3 tahun $-<5$ tahun, 15 orang anak (5,44\%) berumur 5 $<11$ tahun. Dapat dilihat bahwa jumlah penderita terbanyak adalah kelompok umur 1 sampai 3 tahun kemudian berkurang secara berurutan pada kelompok umur lebih tua. Hal ini sesuai dengan kepustakaan bahwa usia merupakan faktor resiko diare, diare akut lebih sering terjadi pada bayi dari pada anak yang lebih tua. ${ }^{12}$

Pada Tabel 7 berdasarkan nilai hematokrit, didapatkan 40 orang anak (14,50\%) dengan nilai hematokrit di bawah normal, 205 orang anak (74,27\%) dengan nilai hematokrit normal, 31 orang anak (11,23\%) dengan nilai hematokrit di atas normal. Nilai terbanyak didapatkan pada pasien dengan hematokrit normal, ini sesuai dengan kepustakaan. Nilai hematokrit yang meningkat ditemukan pada keadaan DHF yang merupakan tanda syok, polistemia, hipoksia. Namun, pada peningkatan hematokrit dapat terjadi dehidrasi berat Nilai hematokrit yang menurun bisa menunjukan adanya perdarahan. ${ }^{1,14}$

Pada Tabel 8 berdasarkan nilai leukosit, didapatkan 22 orang anak (7,98\%) dengan nilai leukosit di bawah normal, 224 orang anak (81,16\%) dengan nilai leukosit normal, 30 orang anak (10,86\%) dengan nilai leukosit di atas normal. Nilai terbanyak adalah pasien dengan nilai leukosit normal. Hal ini sesuai dengan kepustakaan yang mengatakan bahwa nilai leukosit pada anak dengan diare akut adalah normal. ${ }^{15}$ Nilai leukosit yang 
meningkat atau leukositosis terdapat pada keadaan-keadaan sebagai berikut antara lain neoplasma, infeksi bakteri, dan lainlain. Nilai leukosit yang menurun atau leukositopenia biasanya menunjukan adanya inveksi virus. ${ }^{9}$

Pada Tabel 9 berdasarkan nilai hemoglobin, terdapat 37 orang anak $(13,41 \%)$ dengan nilai hemoglobin di bawah normal, 189 orang anak (68,48\%) dengan nilai hemoglobin normal, 50 orang anak $(18,11 \%)$ dengan nilai hemoglobin di atas normal. Nilai terbanyak adalah pasien dengan nilai hemoglobin normal. Hal ini sesuai dengan kepustakaan yang mengatakan bahwa nilai hemoglobin pada diare akut adalah normal. ${ }^{15}$ Nilai hemoglobin yang meningkat terdapat pada pasien dehidrasi, gagal jantung kongestif, dan lain - lain. Nilai hemoglobin yang menurun dapat mengakibatkan anemia pada anak. ${ }^{16}$

Pada Tabel 10 berdasarkan nilai trombosit terdapat, 18 orang anak (6,52\%) dengan nilai trombosit di bawah normal, 196 orang anak (71,01\%) dengan nilai trombosit normal, 62 orang anak (22,47\%) dengan nilai trombosit di atas normal. Nilai terbanyak adalah pasien dengan nilai trombosit normal. Hal ini sesuai dengan kepustakaan yang mengatakan bahwa nilai trombosit pada pasien diare akut adalah normal. ${ }^{15}$

Pada Tabel 11 berdasarkan derajat dehidrasi, terdapat 133 orang anak (48,19\%) tanpa dehidrasi, 132 orang anak $(47,83 \%)$ dengan dehidrasi ringan-sedang, 11 orang anak (3,98\%) dengan dehidrasi berat, dehidrasi merupakan komplikasi utama dari diare. Sesuai dengan kepustakaan bahwa diare akan mengakibatkan kehilangan sejumlah besar air dan elektrolit yang mengakibatkan munculnya gejala-gejala dehidrasi. Tingginya pasien diare akut tanpa dehidrasi menunjukan ketepatan dan kecepatan penanganan orang tua dan dokter sebelum anak dirawat maupun segera setelah anak masuk rumah sakit dan ketika terlihat gejala-gejala dehidrasi. ${ }^{13}$ Pada pasien diare akut dengan dehidrasi berat dapat terjadi peningkatan hemoglobin dan hematokrit. ${ }^{15}$

Pada Tabel 12 berdasarkan nilai hematokrit terdapat 18 orang anak (6,52\%) dengan nilai hematokrit di bawah normal, 196 orang anak $(71,01 \%)$ dengan nilai hematokrit normal, 62 orang anak (22,47\%) dengan nilai hematokrit di atas normal. Dehidrasi mengakibatkan darah lebih kental sehingga nilai hematokrit meningkat namun setelah rehidrasi yang adekuat maka akan kembali normal. ${ }^{14}$

Pada Tabel 13 tidak terdapat anak dengan gizi buruk, 63 orang anak (22,83\%) dengan gizi kurang, 210 orang anak (76,09\%) dengan gizi baik, 2 orang anak $(0,72 \%)$ dengan overweight, 1 orang anak $(0,36 \%)$ dengan obesitas. Menutut kepustakaan status gizi dan diare memiliki asosiasi. Masalah gangguan gizi sebagai akibat kelaparan, masuknya makanan yang kurang tetapi pengeluaran bertambah. ${ }^{13}$

Pada Tabel 14 berdasarkan faktor penyulit terdapat 122 orang anak (44,20\%) yang disertai faktor penyulit, 154 orang anak $(55,80 \%)$ tidak disertai dengan faktor penyulit. Yang terbanyak adalah pasien diare akut dengan adanya faktor penyulit, terdapat 122 orang. Sesuai dengan kepustakaan infeksi parental atau dengan faktor penyulit seperti OMA, tonsilofaringitis, bronkpneumonia, ensefalitis dapat mengakibatkan diare akut. ${ }^{1}$

Pada Tabel 15 berdasarkan lama perawatan terdapat 273 orang anak (98,91\%) yang dirawat $1-\leq 14$ hari, 3 orang anak (1,09\%) yang dirawat $>14$ hari. Hal ini sesuai dengan kepustakaan yang mengatakan bahwa pasien anak dengan diare akut lama perawatan ialah $\leq 14$ hari. ${ }^{8}$

\section{SIMPULAN}

Diare akut lebih sering terjadi pada usia yang lebih muda. Jenis kelamin tidak memengaruhi kejadian diare akut pada anak. Nilai pemeriksaan hematologi diare akut umumnya normal. Nilai hematokrit yang normal pada diare akut tidak menyingkirkan kemungkinan dehidrasi. Lama perawatan pasien diare akut $\leq 14$ hari. 


\section{DAFTAR PUSTAKA}

1. Hassan $\mathbf{R}$, Alatas $H$, editor. Gastroenterologi. Dalam: Buku Kuliah 1 Ilmu Kesehatan Anak. Jakarta: FKUI, 2007; p.283-86.

2. Adisasmito W. Faktor resiko diare pada bayi dan balita di Indonesia. Jakarta, Fakultas Kesehatan Masyarakat-UI, 2007; p. 1-10.

3. Virdayati. Perbandingan manifestasi klinis dan pola epidemiologi infeksi rotavirus dan non-rotavirus pada penderita diare akut di RSMH Palembang. Surabaya: Fakultas Kedokteran-Unair, 2002; p. 1-2

4. Departemen Kesehatan RI dan DITJEN dan PLP,1999. Dalam: Buku Asuhan Keperawatan Anak: Gangguan Sistem Gastrointestinal dan Hepatobilier. Sodikin. Jakarta: Salemba Medika, 2011; p. 223.

5. Departemen Kesehatan RI. Profil Kesehatan Indonesia 2004 Menuju Indonesia Sehat 2010. Pusat Data Kesehatan Indonesia, 2006; p. 275.

6. The United Nation's Children Fund/ World Health Organization. WHO/UNICEF JOINT STATEMENT: Clinical Management of Acute Diarrhoea. 2004. [cited 2011 Nov 16]. Available from:

http://rehydrate.org/diarrhoea/acutediarrhoea.pdf.

7. Anonymous. Diarrhea. 2008. [cited 2011 Nov 16]. Available from: http://digestive.niddk.nih.gov/ddiseas es/pubs/diarrhea/index.aspx.

8. Departemen Kesehatan RI dan DITJEN dan PLP, 1999. In: Buku Asuhan Keperawatan Anak: Gangguan Sistem Gastrointestinal dan Hepatobilier. Sodikin. Jakarta: Salemba Medica,
2011. p. 225 9. Woo $\begin{gathered}\text { J, Henry } \\ \text { Pathologi/laboratory }\end{gathered} \quad$ JB. $\begin{array}{r}\text { Clinikal } \\ \text { Medicine }\end{array}$ Purposes and Practic. In: Henry JB, editor. 18th Edition Clinical and Diagnosis Management by Laboratory Methods. New York: Saunders, 1991; p. 3-21,723-25.

10.Kartini A, Hartawan B, Mandera LI, editor. Aspek Hematologi Penyakit Infeksi dan Sistemik. In: Hematologi Klinik Pendekatan Berorientasi Masalah. Jakarta: Hipokrates; p.22435

11.Koenigsberg R, editor. Churcill's Medical Dictionary. New York: Churchill Livingstone, 1989; p.2021.

12.McCormick. 1982 dikutip Noerasid, Suraatmadja dan Asnil 1988 In: Buku Asuhan Keperawatan Anak: Gangguan Sistem Gastrointestinal dan Hepatobilier. Sodikin. Jakarta: Salemba Medika, 2011; p. 223.

13. Staf Pengajar Ilmu Kesehatan Anak. Buku kuliah Ilmu Kesehatan Anak (9th ed). Hasan $\mathrm{R}$, Alatas $\mathrm{H}$, penyunting. Jakarta: Infomedika, 2000; p. 285.

14. Anonymous. Hematokrit. 2009. [cited 2012 Jan 29]. Available from: http://en.wikipedia.org/ wiki/Hematocrit.

15.Bhutta Z. Acute Gastroenteritis In Children. In: Kliegman R, Berhrman $\mathrm{R}$, Jenson $\mathrm{H}$, Stanton B, editor. Nelson Texbook of Pediatrics (18th ed). Philadelphia: Saunders, 2004; p. 283-17.

16.Hassan $\mathbf{R}$, Alatas $\mathbf{H}$, editor. Gastroenterologi. In: Buku Kuliah 1 Ilmu Kesehatan Anak. Jakarta: FKUI, 2007; p. 435. 